\title{
Tax Fraud and Selective Law Enforcement
}

\author{
RITA DE LA FERIA*
}

This article presents a new conceptual framework for research into tax fraud and law enforcement. Informed by research approaches from across tax law, public economics, criminology, criminal justice, economics of crime, and regulatory theory, it assesses the effectiveness, and the legitimacy, of current approaches to combating tax fraud, bringing new dimensions to previously identified trends in crime control. It argues that, whilst the last decade has witnessed a significant intensification of measures that purportedly target tax fraud, preference has been consistently given to enforcement measures that maximize revenue gains rather than combat the fraud itself, even where the effect is to aggravate the non-revenue costs of tax fraud. These developments demonstrate a significant shift from tax fraud suppression to tax fraud management. The article concludes that this shift not only undermines tax equity and overall tax compliance, but also leads to selective tax enforcement, thus representing a significant risk to the rule of law.

\section{INTRODUCTION}

Tax fraud is, by its very nature, difficult to measure. Although tax administrations commonly present estimations of the levels of fraud, the

\footnotetext{
* School of Law, The Liberty Building, University of Leeds, Leeds, LS2 9JT, England r.delaferia@leeds.ac.uk
}

This article was the subject of my Inaugural Lecture at the University of Leeds (February 2017). In the four years prior, and since then, parts therein were also presented at various conferences and seminars around Europe and North America, as follows: Bilbao, Sofia, Riga, Trier, Newcastle, Helsinki, Lisbon, Berlin, Milan, Warsaw, Munich, Vienna, Oxford, Brussels, Montreal, and Toronto. I am grateful to the organizers and the participants at these events for all of the comments received therein. Thank you also to Conor O'Reilly, Bart Caluwe, Iain Campbell, Allison Christians, Stephen DaIy, Michael Devereux, Joachim Englisch, Joan Loughrey, Jacques Malherbe, Max Schofield, Artur Swistak, Peter Whelan, and two anonymous reviewers for their helpful comments and suggestions. Finally, to Radu Petrescu, for his initial research assistance. The usual disclaimer applies. 
methods used are rarely made public, vary widely, and are often unsuitable. ${ }^{1}$ There is little doubt, however, over its significance, with EU estimates reaching up to $€ 1$ trillion in revenue loss per year. ${ }^{2}$ In countries such as the UK that do publish official aggregate estimates of non-compliance - usually referred to as the tax gap ${ }^{3}$ - the estimated revenue lost to fraud runs into the many billions of euros. ${ }^{4}$ Although these measurements cannot be taken to be fully accurate, ${ }^{5}$ and the gap is a measure of non-compliance in general rather than of revenue loss due to fraud and evasion specifically, these figures are indicative of the scale of the problem. In addition to the official numbers, recent tax scandals involving evidence of widespread tax fraud, such as the Swiss Leaks ${ }^{6}$ and the Panama Papers, ${ }^{7}$ not only presented concrete evidence of the extent of the problem ${ }^{8}$ but equally increased public awareness of it.

Given its significance, it is unsurprising that in the period following the economic and financial crisis in 2008/2009, when EU member states' priority was to ensure fiscal consolidation and public concerns over austerity measures mounted, attention turned more intensively towards tax fraud. ${ }^{9}$ This was

1 IMF, Current Challenges in Revenue Mobilization: Improving Tax Compliance (2015) IMF Staff Paper, at 10. See also N. Artavanis et al., 'Measuring Income Tax Evasion Using Bank Credit: Evidence from Greece' (2016) 131 Q. J. of Economics 739; H. G. Petersen et al., 'Shadow Economy, Tax Evasion, and Transfer Fraud: Definition, Measurement, and Data Problems' (2010) 24 International Economic J. 421.

2 European Commission, 'Huge Sums Are Being Lost due to Tax Evasion and Avoidance' (n.d.), at <https://ec.europa.eu/taxation_customs/fight-against-taxfraud-tax-evasion/a-huge-problem_en $>$.

3 OECD, Tax Administration 2017: Comparative Information on OECD and Other Advanced and Emerging Economies (2017) 181 et seq.

4 HMRC, Measuring Tax Gaps 2019 Edition: Tax Gap Estimates for 2017-2018 (2019), at <https://assets.publishing.service.gov.uk/government/uploads/system/ uploads/attachment_data/file/820979/Measuring_tax_gaps_2019_edition.pdf > .

5 Criticisms of the measurement are summarized in K. Yiallourou, 'The Limitations of the VAT Gap Measurement' (2019) 28 EC Tax Rev. 196.

6 D. Leigh et al., 'HSBC Files Show How Swiss Bank Helped Clients Dodge Taxes and Hide Millions' Guardian, 8 February 2015, at <https://www.theguardian. $\mathrm{com} / \mathrm{business} / 2015 / \mathrm{feb} / 08 / \mathrm{hsbc}$-files-expose-swiss-bank-clients-dodge-taxes-hidemillions $>$.

7 L. Harding, 'What Are the Panama Papers? A Guide to History's Biggest Data Leak' Guardian, 5 April 2016, at <https://www.theguardian.com/news/2016/apr/03/ what-you-need-to-know-about-the-panama-papers $>$. See also J. Londono-Velez and J. Avila-Mahecha, 'Can Wealth Taxation Work in Developing Countries? QuasiExperimental Evidence from Colombia' (2018) working paper. Whilst the leak revealed a range of potentially questionable tax practices, this article concentrates solely on tax fraud rather than avoidance or planning, as these raise significantly different legal questions.

8 A. Alstadserter et al., 'Tax Evasion and Inequality' (2017) NBER Working Paper 23772. See also G. Zucman, The Hidden Wealth of Nations: The Scourge of Tax Havens (2015).

9 On the impact of the crisis on tax policy, see generally R. C. Christensen and M. Hearson, 'The New Politics of Global Tax Governance: Taking Stock a Decade after the Financial Crisis' (2019) 26 Rev. of International Political Economy 1068; 
particular evident with regards to value-added tax (VAT) due to its revenuegathering potential ${ }^{10}$ and its perceived neutrality with respect to economic growth. ${ }^{11}$ The policy commitment to combating tax fraud seems, prima facie, to have worked: available estimates for developed countries indicate a general narrowing of compliance gaps, ${ }^{12}$ even within VAT, where this was not initially the case. In the UK, for example, the overall tax gap has decreased by nearly 2 per cent, and the VAT gap by nearly 4 per cent, between 2005 and $2016 .{ }^{13}$ This decrease has been generally welcomed, with even critics accepting the official explanation that it is the result of increased compliance and lower levels of fraud, ${ }^{14}$ despite acknowledging potential distortions. ${ }^{15}$ This is, however, a false equivalence. Certain measures may eliminate the revenue costs of the fraud, yet not address the fraud itself. As discussed below, a key example would be when additional revenue is collected from non-fraudulent businesses to compensate for what has been lost through fraud, by imposing what is known as third-party liability. In this case, the decrease in the gap may be partly attributed not to the reduction of fraud per se but to the implementation of these measures, which merely maximize revenue collection.

This article presents a novel conceptual framework for understanding the tax fraud phenomenon, informed by research insights from across various disciplines - tax law, public economics, criminology, criminal justice, economics of crime, and regulatory theory - thereby breaking with the single- or dual-discipline orthodoxy that has often characterized previous studies. It then reflects upon both the effectiveness and the legitimacy of antifraud practices by establishing how, through prioritizing short-term revenue gains over the elimination of tax fraud, they: unavoidably lead to selective tax enforcement; damage the neutrality and equity of overall tax systems; decrease the long-term efficiency of those same tax systems, even where there are short-term efficiency gains; and, ultimately, undermine the rule of law. Although these tendencies are evident across different taxes, from tax

I. Grinberg, 'The New International Tax Diplomacy' (2017) 104 Georgetown Law J. 61 . For a detailed analysis of the various exogenous and endogenous factors at play as regards anti-fraud policy, see Section IV.

10 Whilst VAT accounted for over 18 per cent of total tax revenues of EU member states, in some member states it amounted to as much 50 per cent of total tax revenue; see European Commission, Taxation Trends in the European Union: 2017 Edition (2017), at 20-21 and 159, at <https://ec.europa.eu/taxation_customs/sites/taxation/ files/taxation_trends_report_2017.pdf $>$.

11 R. de la Feria, 'Blueprint for Reform of VAT Rates in Europe' (2015) 43 Intertax 154, at 162 .

12 IMF, op. cit, n. 1, at 13.

13 HMRC, op. cit, n. 4.

14 N. Gemmel and J. Hasseltine, 'Taxpayer's Behavioural Responses and Measures of Tax Compliance "Gaps": A Critique and a New Measure' (2014) 35 Fiscal Studies 275.

15 IMF, op. cit., n. 1, at 7 and 13 . 
amnesties in income taxes ${ }^{16}$ to third-party liability in excise duties, and across different (EU and non-EU) countries, VAT is used as a case study, drawing evidence primarily from European countries' practices.

The article is divided into three sections. Section II introduces the new conceptual framework for understanding tax fraud, using VAT as a case study; it presents a broad typology of VAT fraud and considers the various costs of tax fraud. Section III discusses existing measures to tackle tax fraud. In particular, enforcement developments such as penalties, legal formalism, and third-party tax liability are considered in terms of related criminal justice approaches, and the theoretical framework of aggravated responsibilization is introduced as part of a proposed re-conceptualization of law enforcement strategies in the context of tax fraud. Section IV concludes by considering the factors that prompted this policy shift from tax fraud suppression to tax fraud management, as well as the risks that this shift presents, both in terms of the potential creation of a moral hazard that may further propagate tax fraud, and crucially also through the establishment of selective tax enforcement, which undermines the rule of law.

\section{UNDERSTANDING THE TAX FRAUD PHENOMENON}

VAT, like any other type of tax, is vulnerable to fraud. Traditionally, the inclusion of consumption taxes in the tax mix is seen as spreading the risk of enforcement, ${ }^{17}$ and VAT is perceived as less susceptible to fraud than its principal alternative and economic equivalent, the retail sales tax (RST). This comparative advantage is attributable to the multi-stage nature of VAT, which requires the tax to be collected on business-to-business transactions, but also allows businesses to credit the VAT paid on their purchases (inputs) against the VAT charged on their sales (outputs). This multi-stage collection process ensures that: (1) buyers of intermediate goods have opposing interests to the sellers, thus reducing the scope for evasion; ${ }^{18}$ and (2) the risk of evasion is spread across the different elements of the production chain. The characteristics of VAT therefore ensure that it falls, by nature, into the framework of situational crime prevention: designing the tax in a manner that prevents fraud from occurring. ${ }^{19}$ However, whilst the incentive

16 R. C. Bayer et al., 'The Occurrence of Tax Amnesties: Theory and Evidence' (2015) 125 J. of Public Economics 70; K. Baer and E. Le Borge, Tax Amnesties: Theory, Trends, and Some Alternatives (2008).

17 R. Broadway et al., 'Towards a Theory of the Direct-Indirect Tax Mix' (1994) $55 \mathrm{~J}$. of Public Economics 71.

18 A. Sandmo, 'The Theory of Tax Evasion: A Retrospective View' (2005) 58 National Tax J. 643, at 654 .

19 P. Alldridge, Criminal Justice and Taxation (2017), at 34. See also D. Middleton and M. Levi, 'Let Sleeping Lawyers Lie: Organised Crime, Lawyers and the Regulation of Legal Services' (2015) 55 Brit. J. of Criminology 647. 
for traders to ensure that suppliers provide them with credit-allowing invoices gives some guarantee that VAT is, to some extent, self-enforceable ${ }^{20}$ it is also true that this self-enforceability is somewhat illusory. ${ }^{21}$ First, there is some evidence that 'bad production chains' can form; ${ }^{22}$ second, and more importantly perhaps, even where bad chains do not form, self-enforceability does not cover all aspects of the production chain and it is precisely at these points, when the elements of self-enforceability are absent, that fraud tends to occur.

Tax fraud can be largely defined as behaviour aimed at obtaining an unlawful tax advantage and/or causing unlawful tax loss. ${ }^{23}$ Although the means of obtaining such an advantage vary greatly, as do the potential costs resulting from the fraud, there is often a failure to grasp the complexity of the phenomenon, which is then reflected in the inadequacy of the measures adopted to combat it. Understanding the phenomenon of VAT fraud is therefore a necessary preliminary step towards critical assessment of measures to address it.

\section{A typology of VAT fraud}

There have been a number of attempts to provide a typology of VAT fraud. Some have focused on the distinction between those types of fraud that are common to all taxes and those that are specific to VAT, ${ }^{24}$ some have concentrated on the differences between the types of perpetrators, ${ }^{25}$ and some have concentrated on chronology. ${ }^{26}$ Given the constant mutations in behavioural patterns, providing a definitive typology of VAT fraud is, by its nature, difficult. However, it is argued that the main distinction, which applies to tax fraud more generally, is that between evasion and organized

20 D. Pomeranz, 'No Taxation Without Information: Deterrence and Self-Enforcement in the Value Added Tax' (2015) 105 Am. Economic Rev. 2539. See also M. Waseem, 'Information, Asymmetric Incentives, or Withholding? Understanding the Self-Enforcement of Value-Added Tax' (2018) Oxford University Centre for Business Taxation Working Paper WP 18/08.

21 M. Keen and S. Smith, "VAT Fraud and Evasion: What Do We Know and What Can Be Done?' (2006) 59 National Tax J. 861.

22 A. de Paula and J. A. Scheinkman, 'Value-Added Taxes, Chain Effects and Informality' (2010) 2 Am. Economic J.: Macroeconomics 195.

23 For a definition of fraud generally, see M. Levi and J. Burrows, 'Measuring the Impact of Fraud in the UK' (2008) 48 Brit. J. of Criminology 293.

24 Keen and Smith, op. cit., n. 21.

25 UK National Audit Office, Tackling Tax Fraud: How HMRC Responds to Tax Evasion, the Hidden Economy, and Criminal Attacks (2015), at $<\mathrm{https}$ :/www. nao.org.uk/wp-content/uploads/2015/12/Tackling-tax-fraud-how-HMRC-respondsto-tax-evasion-the-hidden-economy-and-criminal-attacks.pdf $>$.

26 M. Lamensch, 'Fraude TVA et Commerce Digital' in La Fraude à la TVA, ed. C. Herbain (2017) 127. 


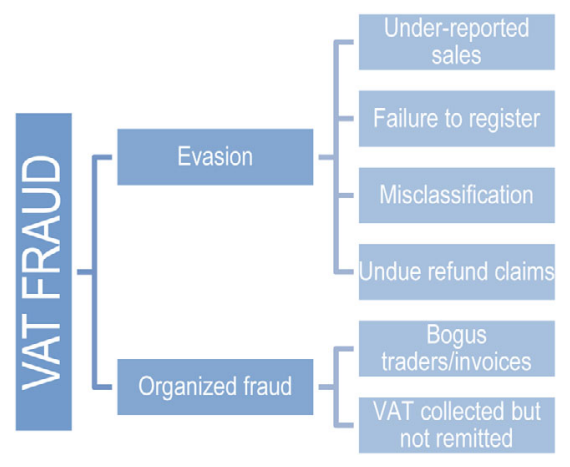

fraud. Although this distinction does connect with the type of perpetrator, ${ }^{27}$ its primary focus is on the means used to obtain an unlawful tax advantage. Evasion results from either informality or part-time crime, and can be defined as the deliberate omission, concealment, or misrepresentation of information to reduce VAT liability. Organized fraud, on the other hand, involves coordinated and systematic actions, with varying levels of sophistication and organization, towards obtaining an unlawful VAT financial advantage. ${ }^{28}$ These two behavioural types are also typified by divergent characteristics in terms of perpetrators, geographical reach, methods, and costs. Evasion tends to be carried out by small companies, ${ }^{29}$ operating at a national level - although no longer exclusively so - who take advantage of national administrative limitations and distinctions in the tax base. Organized fraud tends to be carried out by criminal gangs operating at a transnational level, who take advantage of tax authorities' enforcement limitations regarding cross-border trade. These two categories of VAT fraud also give rise to different types of costs. Organized fraud tends to result in higher levels of revenue loss and a subsidy to organized crime networks, whereas evasion tends to have a bigger impact upon tax inequity and creates an uneven playing field. These distinctions are summarized in Table 1.

Both evasion and organized fraud can be further subdivided into various sub-types, as set out in Figure 1. It should be noted that these types/subtypes are indicative rather than rigidly distinct; there are reports of hybrid

27 M. Levi, 'Serious Tax Fraud and Non-Compliance: A Review of Evidence on the Differential Impact of Criminal and Non-Criminal Proceedings' (2010) 9 Criminology \& Public Policy 493.

28 Organized fraud is also evident within income taxation; see T. Buettner et al., 'Withholding-Tax Non-Compliance: The Case of Cum-Ex Stock-Market Transactions' (2018), at <https://ssrn.com/abstract=2960015>.

29 UK National Audit Office, op. cit., n. 25. See also Pomeranz, op. cit., n. 20; H. J. Kleven et al., 'Why Can Modern Governments Tax So Much? An Agency Model of Firms as Fiscal Intermediaries' (2016) 83 Economica 219. 
Table 1. VAT evasion vs organized fraud

\begin{tabular}{|c|c|c|}
\hline & EVASION & ORGANIZED FRAUD \\
\hline Definition & $\begin{array}{l}\text { Results from informality } \\
\text { or part-time crime } \\
\text { Deliberate omission, } \\
\text { concealment, or } \\
\text { misrepresentation of } \\
\text { information to reduce } \\
\text { VAT liability }\end{array}$ & $\begin{array}{l}\text { Coordinated and } \\
\text { systematic actions, with } \\
\text { varying levels of } \\
\text { sophistication and } \\
\text { organization, with the } \\
\text { aim of obtaining an } \\
\text { unlawful VAT financial } \\
\text { advantage }\end{array}$ \\
\hline $\begin{array}{l}\text { Type of } \\
\text { perpetrators }\end{array}$ & Primarily small companies & $\begin{array}{l}\text { Carried out largely by } \\
\text { organized criminal } \\
\text { gangs }\end{array}$ \\
\hline $\begin{array}{l}\text { Geographical } \\
\text { reach }\end{array}$ & $\begin{array}{l}\text { Traditionally operating at } \\
\text { local, regional, or } \\
\text { national levels, although } \\
\text { spreading as a result of } \\
\text { the digitalization of the } \\
\text { economy }\end{array}$ & $\begin{array}{l}\text { Primarily operating } \\
\text { transnationally across } \\
\text { borders }\end{array}$ \\
\hline Method & $\begin{array}{l}\text { Take advantage of national } \\
\text { administrative } \\
\text { limitations and } \\
\text { distinctions in the tax } \\
\text { base }\end{array}$ & $\begin{array}{l}\text { Take advantage of } \\
\text { enforcement limitations } \\
\text { by tax administrations } \\
\text { on cross-border trade }\end{array}$ \\
\hline Type of costs & $\begin{array}{l}\text { Primarily tax inequity and } \\
\text { the creation of an } \\
\text { uneven playing field }\end{array}$ & $\begin{array}{l}\text { Primarily revenue loss, } \\
\text { subsidy to organized } \\
\text { crime, compliance and } \\
\text { administrative costs }\end{array}$ \\
\hline
\end{tabular}

fraud, which combines evasion (under-reporting of sales) with organized fraud (bogus traders/invoices). ${ }^{30}$

Whilst a detailed analysis of the various sub-types of VAT fraud is outside the scope of this article, ${ }^{31}$ the most frequent types of organized fraud are worthy of further consideration. Bogus traders, also known as 'invoice mills', are companies set up solely for the purpose of selling invoices. In these circumstances, the underlying sale of goods or services never takes place, and the actual sale is that of the invoice giving the right to VAT refund. The fraud therefore requires collusion between seller and purchaser, as well as a significant level of organization. Litigation concerning bogus traders

30 K. V. Pashev, 'Countering Cross-Border VAT Fraud: The Bulgarian Experience' (2007) 14 J. of Financial Crime 490.

31 On under-reporting software programs, known as zappers, see R. T. Ainsworth, 'Zappers: Retail VAT Fraud' (2010) 3 International VAT Monitor 175. On failure to register, see B. Lockwood and L. Liu, 'VAT Notches' (2016) Oxford University Centre for Business Taxation Working Paper WP 16/10. 
seems to indicate high levels of this type of fraud, primarily in Eastern European member states. ${ }^{32}$ As regards VAT collected but not remitted to the government, whilst there are various possible methods to commit this type of fraud - such as false accounting, engineering bankruptcy, and VAT number hijacking - the most important is undoubtedly missing-trader fraud (MTF).

MTF exploits two key features of the VAT system: (1) the time lag between the collection of the tax and its remittance; and (2) the principle that requires all exports to be VAT-free, with tax collected solely on imports. In its simplest form, a trader - the missing trader in the MTF - collects VAT paid to him/her by a supplier without accounting or remitting to the tax authorities and disappears before the authorities realize what has occurred. ${ }^{33}$ There are numerous variations of this basic model: the same goods may move around different chains, with all of the traders in the chain involved, or aware that the fraud is occurring (carousel fraud); or different goods may be sold to unsuspecting third parties by fraudsters, who thereby insert themselves into legitimate production chains (MTF). Whilst these fraud schemes have traditionally operated within the EU, similar schemes have now developed involving non-EU countries. ${ }^{34}$

Whilst its manifestations differ, as the analysis below will demonstrate, ${ }^{35}$ the shift in anti-fraud policy, where the focus has been exclusively on revenue loss and revenue maximization, can be witnessed across the fraud spectrum, encompassing both measures reportedly aimed at combating evasion and those aimed at tackling organized fraud.

\section{The costs of tax fraud}

Measuring the costs of fraud, like measuring its level, is inherently difficult. ${ }^{36}$ As such, revenue losses are generally used as the basis by which to estimate the level of fraud. ${ }^{37}$ Insofar as VAT is concerned, since 2004, it has often been asserted that fraud accounts for approximately 10 per cent of VAT revenue within the EU; ${ }^{38}$ more recently, however, the VAT gap within the EU has been estimated to be $€ 150$ billion, or 12.8 per cent of the revenue collected, but

32 Case C-527/11 Ablessio ECLI:EU:C:2013:168 (Latvia); Case C-107/13 FIRIN ECLI:EU:C:2014:151 (Bulgaria).

33 Case C-354/03 Optigen and Others, ECLI:EU:C:2005:89, para. 8.

34 F. Borselli, 'Pragmatic Policies to Tackle VAT Fraud in the European Union' (2008) 5 International VAT Monitor 333.

35 See Section III below.

36 Levi and Burrows, op. cit., n. 23.

37 L. Barbone et al., The Costs of VAT: A Review of the Literature, CASE Network No. 106/2012, at 46 et seq; C. W. Nam et al., 'Measurement of Value Added Tax Evasion in Selected EU Countries on the Basis of National Accounts Data' (2001) CESifo Working Paper 431.

38 European Commission, Report from the Commission to the Council and the European Parliament on the Use of Administrative Cooperation Arrangements in the Fight against VAT Fraud (2004) COM(2004) 260 final, at 5. 
no precise figures for fraud are available. ${ }^{39}$ Similarly in the UK, whilst HM Revenue \& Customs (HMRC) has estimated the VAT gap to be 9.8 per cent of total revenue for 2015-2016, no estimates have been offered for overall VAT fraud, although some types of fraud have been quantified. ${ }^{40}$ Europol has also offered estimates for MTF, reporting that EU countries lose $€ 100$ billion annually to that one type of fraud - a perhaps suspiciously neat rounded figure. ${ }^{41}$ Whilst the above are, of course, mere estimates - methodological difficulties in establishing precise figures are openly acknowledged by tax administrations $^{42}$ - it is nevertheless reasonable to assume that the share of revenue lost within the EU to VAT fraud is considerable. This is also supported by evidence of the increased scale of fraud, with some individual instances of fraud so massive as to account in isolation for a significant amount of revenue loss. ${ }^{43}$

These estimates also highlight the extent to which measuring VAT fraud has been equated with measuring the revenue costs of VAT fraud. Whilst this seems an instinctively reasonable approach, given the difficulties in measuring fraud directly, it also gives rise to the common misconception that the only costs of VAT fraud are revenue costs. Despite some institutions, such as the European Commission or the IMF, occasionally acknowledging the existence of other costs beyond lost revenue, ${ }^{44}$ and similarly some tax authorities, ${ }^{45}$ it is clear that the focus in reports concerning VAT fraud is

39 European Commission, Study and Reports on the VAT Gap in the EU-28 Member States: 2017 Final Report (2017) TAXUD/2015/CC/131, at $<$ https://ec.europa. eu/taxation_customs/sites/taxation/files/study_and_reports_on_the_vat_gap_2017. pdf $>$.

40 HMRC, op. cit., n. 4.

41 Europol, EU Serious and Organized Crime Threat Assessment (2013).

42 European Court of Auditors, Tackling Intra-Community VAT Fraud: More Action Needed (2015) Special Report No. 24, at <https://www.eca.europa.eu/Lists/ ECADocuments/SR15_24/SR_VAT_FRAUD_EN.pdf $>$.

43 One of the most infamous cases was the $\mathrm{CO}_{2}$ fraud in 2008/2009; see Europol, Carbon Credit Fraud Causes More than 5 Billion Euros Damage for European Taxpayer, 9 December 2009, at <https://www.europol.europa.eu/newsroom/news/carbon-creditfraud-causes-more-5-billion-euros-damage-for-european-taxpayer $>$. See also P. Efstratios, 'Halting the Horses: EU Policy on the VAT Carousel Fraud in the EU Emissions Trading System' (2012) 1 EC Tax Rev. 39; R. A. Wolf, 'A Sad History of Carbon Carousels' (2010) 21 International VAT Monitor 403. On other reported instances of massive fraud, see Eurojust, EU-Wide Fuel Oil and Precious Metals VAT Fraud and Money Laundering Network Dismantled, 21 December 2016, at $<\mathrm{http}$ : //www.eurojust.europa.eu/press/PressReleases/Pages/2016/2016-12-21.aspx > ;

Europol, Eight Member States Take Action against International VAT Fraud, 29 June 2016, at <https://www.europol.europa.eu/newsroom/news/eight-members-statestake-action-against-international-vat-fraud>; J. Oliver, 'Scams Steal £8.4bn from Taxpayer', BBC One Panorama (2006).

44 European Commission, op. cit., n. 39, at 5; IMF, op. cit., n. 1, at 7.

45 HM Revenue \& Customs, Levelling the Tax Playing Field (2013) compliance progress report, at $<\mathrm{https} / /$ www.gov.uk/government/publications/levelling-the-tax-playingfield >; Canada Revenue Agency, Tax Gap in Canada: A Conceptual Study (2016), 


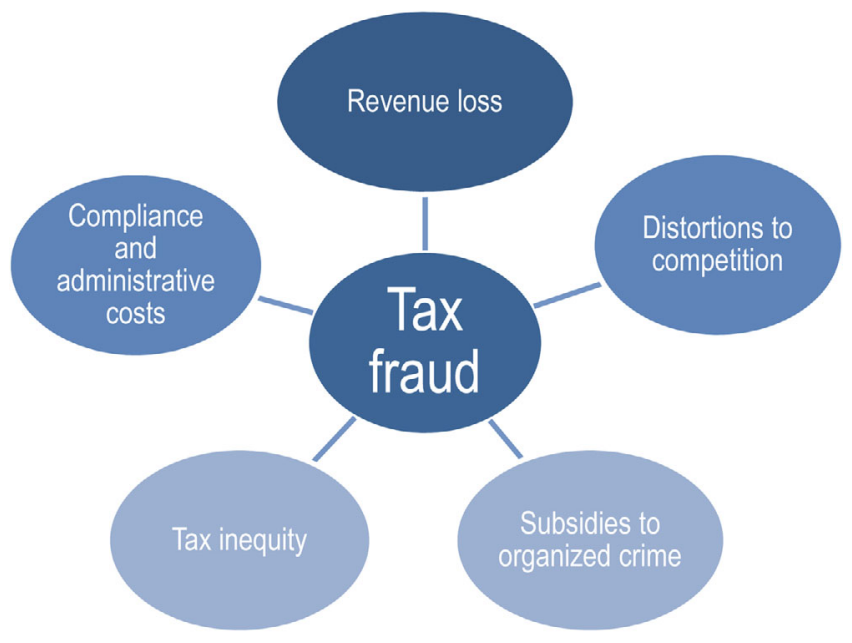

largely on revenue loss. However, as with other types of fraud, revenue loss - or transfer costs - is just one of the problems associated with VAT fraud. Generally, fraud costs can be disaggregated into various components: costs of preventing fraud (anticipatory costs), costs of responding to fraud, and negative externalities. ${ }^{46}$ All are evident in VAT fraud, and in tax fraud more broadly. Apart from revenue loss, and as demonstrated in Figure 2, tax fraud gives rise to significant compliance and administrative costs for both tax administrations and businesses, and to significant negative spillovers: distortions to competition, tax inequity, and subsidies to organized crime. Some of these are new resource costs, rather than transfer costs, which have detrimental effects on economic welfare. ${ }^{47}$

Tax fraud can impose significant costs upon legitimate traders by creating distortions to competition. A lobby group set up by UK-based small and medium-sized enterprises (SMEs) has been drawing attention to the distortive problems caused by alleged VAT fraud perpetrated online by non-EU traders, ${ }^{48}$ and research increasingly substantiates these anecdotal reports. Economic models indicate that tax-evading firms are likely to drive non-

at $\quad<$ https://www.canada.ca/en/revenue-agency/corporate/about-canada-revenueagency-cra/tax-canada-a-conceptual-study $>$.

46 Levi and Burrows, op. cit., n. 23.

47 M. Feldstein, 'Tax Avoidance and the Deadweight Loss of Income' (1999) 81 Rev. of Economics and Statistics 674; R. Chetty, 'Is the Taxable Income Elasticity Sufficient to Calculate Deadweight Loss? The Implications of Evasion and Avoidance' (2009) 1 Am. Economic Rev.: Economic Policy 31.

48 Campaign against VAT Fraud on eBay \& Amazon in the UK, at $<$ http://www. vatfraud.org $>$. 
evading ones out of the market; ${ }^{49}$ and although there are few empirical studies, those that do exist confirm that this impact can be highly significant for affected industries. ${ }^{50}$ The impact is also likely to affect SMEs more severely than bigger firms, as the latter's cash-flow levels allow them to better respond to these distortive effects. Finally, there is also evidence that fraud results in less frequent and lower-quality trade in affected industries, as non-evading firms refrain from engaging in trade or divert trade where they suspect that businesses are involved in tax fraud. Once again, research into these 'hidden costs' of fraud seems to confirm anecdotal reports suggesting that bigger businesses are now wary of trading with SMEs for fear of becoming inadvertently involved in VAT fraud and the resulting costs associated with it. ${ }^{51}$

Directly connected with the distortive costs of tax fraud are its effects on tax equity. ${ }^{52}$ Tax equity is one of the key taxation principles, and it is usually divided into horizontal equity, according to which taxpayers in similar circumstances should be subject to similar tax burdens, and vertical equity, which broadly requires that those with higher incomes carry a higher tax burden than those with lower incomes. ${ }^{53}$ Tax fraud tends to undermine vertical equity and thus results in a more regressive tax system, ${ }^{54}$ because in the absence of a counteracting effect of tax morality, ${ }^{55}$ those with higher incomes are more likely to be able to engage in fraud. ${ }^{56}$ Whilst there is an ongoing debate on the role of vertical tax equity within consumption taxes, ${ }^{57}$ tax equity in its horizontal dimension is a key principle of VAT, as it is of any tax. ${ }^{58}$ Violations of horizontal tax equity are therefore regarded as serious flaws in any tax arrangement. ${ }^{59}$ Tax fraud, by definition, introduces an element of horizontal tax inequity into the tax system, insofar as it results in similarly situated taxpayers facing dissimilar tax burdens.

49 J. Strand, 'Tax Distortions, Household Production, and Black-Market Work' (2005) 21 European J. of Political Economy 851.

50 M. C. Frunza et al., 'Missing Trader Fraud on the Emissions Market' (2011) 18 J. of Financial Crime 183.

51 L. Boulafoutas et al., 'The Hidden Costs of Tax Evasion: Collaborative Tax Evasion in the Markets for Expert Services' (2015) 129 J. of Public Economics 14.

52 This has been termed 'social fairness' by criminologists; see Levi, op. cit., n. 27.

53 D. Elkins, 'Horizontal Equity as a Principle of Tax Theory' (2006) 24 Yale Law and Policy Rev. 43.

54 J. Slemrod and S. Yitzhaki, 'Tax Avoidance, Evasion and Administration' in Handbook of Public Economics, Volume 3, eds. A. Auerbach and M. Feldstein (2002) 1423.

55 K. Lee, 'Morality, Tax Evasion and Equity' (2016) 82 Mathematical Social Sciences 97.

56 Alstadserter et al., op. cit., n. 8 .

57 de la Feria, op. cit., n. 11.

58 However, this is not universally accepted; see L. Kaplow, 'Horizontal Equity: New Measures, Unclear Principles' (2000) NBER Working Paper 7649.

59 Elkins, op. cit., n. 53, at 44. For a different conception of the term, see L. Murphy and T. Nagel, The Myth of Ownership (2002). 
Any tax break - either by design, as a result of tax policy, or by accident, as a result of tax fraud - is in essence a redistribution from those who do not get it to those who do. ${ }^{60}$ In the case of consumption taxes such as VAT, how that impact is felt and by whom depends on the type and circumstances of the fraud. Assuming that the incidence of these taxes falls on consumers as taxpayers, ${ }^{61}$ inequity can arise amongst consumers; where fraudulent businesses charge less tax, and thus a lower price, than non-fraudulent ones in order to obtain a competitive advantage, inequity may also arise; where tax is charged to consumers equally by all businesses, but fraudulent ones fail to remit it to tax administrations, the latter also obtain a financial advantage. In between these key alternatives, there are many hybrid situations where tax inequity arises amongst both consumers and businesses - for example, where fraudulent businesses charge only part of the tax due to consumers, but fail to remit any to tax authorities.

That VAT fraud creates horizontal tax inequity is not only relevant per se but also because there is strong evidence that perceptions of tax equity impact upon compliance levels. ${ }^{62}$ In particular, tax inequity undermines what has been referred to as tax morale: taxpayers' self-regulatory mechanism that cognitively frames paying taxes as doing 'the right thing' ${ }^{63}$ Where there is perceived tax inequity, taxpayers are less likely to think morally, and more likely to respond to taxation through defiance, ${ }^{64}$ as the sense of the fairness of the tax system is important for general tax compliance. ${ }^{65}$ Conversely, economic evidence indicates that non-evading taxpayers derive direct utility from tax enforcement on evaders, regardless of any monetary returns, ${ }^{66}$ as confirmed by recent behavioural science experiments. ${ }^{67}$

Whilst the links between tax fraud generally and other criminal activities, such as money laundering, have long been suspected, ${ }^{68}$ the links specifically

60 Murphy and Nagel, id., at 164.

61 This will depend on market circumstances; see de la Feria, op. cit., n. 11.

62 J. Slemrod, 'Cheating Ourselves: The Economics of Tax Evasion' (2007) $21 \mathrm{~J}$. of Economic Perspectives 25, at 38 et seq; D. Onu and L. Oats, 'The Role of Social Norms in Tax Compliance: Theoretical Overview and Practical Implications' (2015) 1 J. of Tax Administration 113.

63 V. Braithwaite, Defiance in Taxation and Governance: Resisting and Dismissing Authority in a Democracy (2009), at 148-158.

64 V. Braithwaite, 'Tax Evasion' in Handbook on Crime and Public Policy, ed. M. Tonry (2009) 381, at 384; L. Casaburi and U. Troiano, 'Ghost-House Busters: The Electoral Response to a Large Anti-Evasion Program' (2016) 131 Q. J. of Economics 273, at 309.

65 H. Filipczyk, Tax Avoidance and Rationality of Law (2017), at 357-358.

66 Casaburi and Troiano, op. cit., n. 64, at 9.

67 D. Halpern, Inside the Nudge Unit: How Small Changes Can Make a Big Difference (2015), at 112-115; M. Hallsworth et al., 'The Behavioralist as Tax Collector: Using Natural Field Experiments to Enhance Tax Compliance' (2017) 148 J. of Public Economics 14.

68 M. Levi, 'Money for Crime and Money from Crime: Financing Crime and Laundering Crime Proceeds' (2015) 21 European J. of Criminal Policy Research 275. 
between VAT fraud and organized crime were less well known, ${ }^{69}$ despite the fact that the risk of organized fraud, particularly through the use of fake invoices or supplies, is inherent to VAT systems. ${ }^{70}$ This connection, and the use of tax fraud as a method of financing illegal activities, has now been acknowledged by EU institutions ${ }^{71}$ and is a common feature of media reports. ${ }^{72}$ Whilst there are reports of various types of VAT fraud perpetrated by organized crime networks, ${ }^{73}$ MTF seems to be a particularly attractive source of financing for organized crime and paramilitary groups. Although official acknowledgement of such links is recent, their existence has been described in criminological research since the early 1990s. ${ }^{74}$ Previous experience in the Benelux countries had already indicated that the VAT system was vulnerable to organized fraud $;^{75}$ and in the late 1980s and early 1990s research alerted the European Commission to the possibility that intra-EU VAT fraud was about to establish itself in the form of crime networks. ${ }^{76}$ According to field experts, the feared flow of mega-frauds did not emerge immediately; instead, criminal activity is said to have started over a twoyear period. At first, so-called veterans tested the system and how easy it was to commit VAT fraud; they were then followed by some 'legitimate'

69 M. Levi, 'Organized Fraud and Organizing Frauds: Unpacking Research on Networks and Organization' (2008) 8 Criminology and Criminal Justice 389.

70 Keen and Smith, op. cit., n. 21, at 867-868. See also A. Tait, Value-Added Tax: International Practice and Problems (1988), at 307.

71 European Court of Auditors, op. cit., n. 42; Europol, op. cit., n. 41; Europol, op. cit., n. 43. See also HM Government, Serious and Organised Crime Strategy (2013), at <https://www.gov.uk/government/publications/serious-organised-crimestrategy >; Center for the Study of Democracy, Financing of Organised Crime (2015), at 61 et seq.

72 S. O'Driscoll, 'Man Who Paid Dissident's Bail Ran Northern Ireland's Biggest Ever Money-Laundering Scam' Belfast Telegraph, 28 April 2017, at $<$ https://www.belfast telegraph.co.uk/news/northern-ireland/man-who-paid-dissidents-bail-ran-northernirelands-biggest-ever-money-laundering-scam-35661638.html>; A. Travis and A. Seager, 'Reid Wants Europe to Fight VAT Fraud Linked to Terror Funds' Guardian, 26 October 2006, at <https://www.theguardian.com/politics/2006/oct/26/eu. terrorism>

73 A. Berwick and D. Lague, 'Special Report: The Immigrant Success Story that Led Spanish Police to a Chinese Banking Behemoth' Reuters, 1 August 2017, at $<$ https://www.reuters.com/article/us-icbc-chinese-specialreport/the-immigrantsuccess-story-that-led-spanish-police-to-a-chinese-banking-behemoth-idUSKBN $1 \mathrm{AH} 40 \mathrm{G}>$.

74 P. van Duyne, 'VAT Fraud and the Policy of Global Ignorance' (1999) 1 European J. of Law Reform 425; S. White, 'VAT Revenue and Organised Crime: Time for Action?' (1999) 24 European Law Rev. 433.

75 Y. Fedchyshyn, 'Postponed Accounting in the European Union' (2014) 1 International VAT Monitor 11; C. Amand and K. Boucquez, 'A New Defense for Victims of EU Missing-Trader Fraud?' (2011) 4 International VAT Monitor 234, at 236.

76 van Duyne, op. cit., n. 74, at 434. 
traders; ${ }^{77}$ and finally the 'legitimate' and 'criminal' entrepreneurs started to cooperate. ${ }^{78}$

Compliance and administrative costs are second-order costs, resulting not from fraud itself but from its spread. For non-fraudulent businesses and for tax administrations, there are two main types of costs: (1) anticipatory costs, where those entities take measures to prevent involvement in fraud (businesses) or to deter fraud (tax administrations), such as the implementation of new software or due diligence; and (2) reactive costs, where fraud has taken place, and costs arise in the context of inadvertently engaging with fraudsters (businesses) or pursuing civil or criminal actions against fraudsters (tax administrations). ${ }^{79}$ There is evidence that evasion in particular also gives rise to resource costs for fraudsters, as they try to conceal the fraud ${ }^{80}$ or, in the case of risk-averse fraudsters, as a result of the uncertainty created by engaging in fraud. ${ }^{81}$

Although the above costs of tax fraud are significant, and often nominally recognized, the analysis below demonstrates that they seem to have been largely ignored in the context of anti-fraud policy, where the focus has been exclusively on revenue loss, with significant consequences for tax enforcement. This is the case both where policies are primarily aimed at tackling evasion (penalties and legal formalism) and where they are primarily aimed at tackling organized fraud (third-party liability principle).

\section{TACKLING TAX FRAUD}

The approach to tackling tax fraud has traditionally been relatively unsophisticated, relying primarily on penalties and other administrative and criminal sanctions. Despite attracting significant academic attention, ${ }^{82}$ there has been a sense that, from a tax administration perspective, primarily in developed countries, ${ }^{83}$ further investment in tackling fraud may have been perceived as inefficient, as the difficulties and human resources costs involved

77 P. C. van Duyne, 'Organized Crime, Corruption and Power' (1997) 26 Crime, Law and Social Change 201.

78 On the parasitic relationship between legitimate and organized crime traders, see A. Aronowitz et al., Value-Added Tax Fraud in the European Union (1996).

79 Levi and Burrows, op. cit., n. 23.

80 R. C. Bayer, 'A Contest with the Taxman: The Impact of Tax Rates on Tax Evasion and Wastefully Invested Resources' (2006) 50 European Economic Rev. 1071.

81 S. Yitzhaki, 'A Note on Optimal Taxation and Administrative Costs' (1979) 69 Am. Economic Rev. 475.

82 M. G. Allingham and S. Sandmo, 'Income Tax Evasion: A Theoretical Analysis' (1972) 1 J. of Public Economics 323.

83 In developing countries, attention has tended to be greater; see R. de la Feria and A. Schoeman, 'Addressing VAT Fraud in Developing Countries: The Tax PolicyAdministration Symbiosis' (2019) 47 Intertax 950. 
in adopting a stricter approach outweighed the potential revenue benefits. ${ }^{84}$ The last decade, however, has seen a massive shift in this approach, with increased attention being paid to anti-fraud policy. Whilst there are various factors at play, ${ }^{85}$ this shift has undoubtedly been due in part to better understanding of how to combat fraud, and the availability of new tools to do so, in particular promising developments in behavioural science from responsive regulation ${ }^{86}$ to nudge theories ${ }^{87}$ - as well as the use of new technologies, ${ }^{88}$ all of which allow a stricter approach to enforcement at a lower cost than traditional methods. Although these are clearly positive developments, the wider picture on anti-fraud policy is not as inspiring.

\section{Penalties and legal formalism}

Whilst behavioural science has provided new insights into tax compliance and the reasons behind tax evasion, ${ }^{89}$ the traditional view stems largely from economics-of-crime theories according to which taxpayers weigh the expected benefits of tax fraud with the uncertain prospect of detention and punishment. ${ }^{90}$ According to this view, audits, penalties, and other negative compliance incentives were not just effective anti-evasion methods, they were the only methods. ${ }^{91}$ Following this traditional approach, all EU member states have been applying penalties and other negative compliance incentives for a long time, with the majority dividing these into two categories: (1) civil penalties applied to minor compliance offences, and (2) criminal penalties applied to tax evasion actions. ${ }^{92}$ The last decade, however, has seen in many EU member states a marked toughening of the penalties regime.

As is also evident in recent Court of Justice of the European Union (CJEU) case law, this toughening has been reflected not only in the number of

84 A. Plumley, The Determinants of Individual Income Tax Compliance (1996) Department of the Treasury Internal Revenue Service Publication 1916, at 40. See Section IV below on the cost-benefit analysis undertaken by tax administrations.

85 See Section IV below.

86 J. Freedman, 'Responsive Regulation, Risk, and the Rules: Applying the Theory to Tax Practice' (2012) 44 University of British Columbia Law Rev. 627; I. Ayres and J. Braithwaite, Responsive Regulation: Transcending the De-Regulation Debate (1992).

87 Halpern, op. cit., n. 67.

88 OECD, Technologies for Better Tax Administration: A Practical Guide for Revenue Bodies (2016); OECD, Technology Tools to Tackle Tax Evasion and Tax Fraud (2017); R. Bird and E. Zolt, 'Technology and Taxation in Developing Countries: From Hand to Mouse' (2008) 61 National Tax J. 791.

89 J. Slemrod, 'Tax Compliance and Enforcement: New Research and Its Policy Implications' (2016) Ross School of Business Paper 1302.

90 J. Alm et al., 'Why Do People Pay Taxes?' (1992) 48 J. of Public Economics 21, at 21-22.

91 Allingham and Sandmo, op. cit., n. 82; J. Dubin and L. Wilde, 'An Empirical Analysis of Federal Income Tax Auditing and Compliance' (1988) 41 National Tax J. 61.

92 R. Seer and A. L. Wilms (eds), Surcharges and Penalties in Tax Law (2016) EATLP International Tax Series, Vol. 14 Chapters 12-31. 
penalties issued and the level of penalties charged but also in the diversity of penalties, which now include in some EU member states not only financial charges but also the removal of tax rights. ${ }^{93}$ Whilst penalty regimes are not harmonized at the EU level, and member states are therefore free to choose the penalties that seem most appropriate, the CJEU has consistently reiterated that this power must nevertheless be exercised in accordance with general principles of EU law, and in particular the principle of proportionality, ${ }^{94}$ as is also now enshrined in Article 49(3) of the Charter of Fundamental Rights. In order to comply with this principle, penalties must therefore be suitable (they are appropriate to attain the stated aim) and necessary (they do not go beyond what is necessary to attain that aim). The aim against which proportionality is to be assessed is the dual function of penalties: a punitive function and a deterrence function. ${ }^{95}$ Proportionate penalties are therefore those that are appropriate to punish and deter non-tax compliance, and that do not go beyond what is necessary to act as a punishment or a deterrent. ${ }^{96}$

When evaluating whether the principle of proportionality has been respected, the Court tends to concentrate on the second element of the proportionality test - namely, whether the penalties in question go beyond what is necessary to deter fraud. In this regard, member states must consider inter alia the nature and the seriousness of the breach, and the scale of the penalty, ${ }^{97}$ the correlation between the breach and the penalty imposed, ${ }^{98}$ and whether there was actual revenue loss. ${ }^{99}$ For example, Latvian penalties for failure to register, which are aimed at recovering the estimated amount of tax that would have been due had registration taken place, ${ }^{100}$ and Hungarian penalties charged where no loss of revenue has occurred and there is no evidence of evasion, ${ }^{101}$ or where the error has been rectified, ${ }^{102}$ have been deemed disproportionate by the Court. ${ }^{103}$

The Court has rarely made reference to the suitability of penalties, the first element of the proportionality test. Rather, their suitability seems to be assumed, based on the traditional understanding as regards the effectiveness of penalties, and the sense that the higher the penalty, the stronger the

93 Case C-284/11, EMS-Bulgaria Transport, ECLI:EU:C:2012:458.

94 Case C-210/94, Siesse, ECLI:EU:C:1995:351, at para. 21.

95 On the applicability of Article 6 of the European Convention on Human Rights (ECHR), see G. Marino, 'Limitation of Administrative Penalties by the European Convention on Human Rights and the EU Charter of Fundamental Rights' in Seer and Wilms (eds), op. cit., n. 92, 133.

96 Case C-183/14, Salomie and Oltean, ECLI:EU:C:2015:454, at para. 51.

97 Case C-259/12, RODOPI-M 91, ECLI:EU:C:2013:414, at para. 38.

98 Case C-263/11, Rēdlihs, ECLI: EU:C:2012:497, at paras 49-50.

99 Case C-284/11, EMS-Bulgaria Transport, ECLI:EU:C:2012:458, at paras 73-74.

100 Case C-263/11, Rēdlihs, ECLI: EU:C:2012:497.

101 Case C-564/15, Farkas, ECLI:EU:C:2017:302.

102 Case C-368/09, Pannon Gép Centrum, ECLI:EU:C:2010:441.

103 National courts have also reacted against the new approach to penalties; see Mark Richard Beardwood v. HMRC [2018] UKFTT 99 (TC). 
deterrence. ${ }^{104}$ Yet there is now strong empirical evidence that indicates that such effectiveness is far from guaranteed. Even disregarding recent developments in behavioural economics, empirical research suggests that the risk of audit is a much stronger incentive to compliance than penalties, ${ }^{105}$ as are in-person visits, due to their network effects, ${ }^{106}$ and well-designed, targeted letters. ${ }^{107}$ Contrary to the traditional economic deterrence theory, ${ }^{108}$ recent evidence indicates that the risk of penalty can be effective on late compliers, but not on non-compliers. ${ }^{109}$

Often unnecessarily burdensome, and with questions raised over its suitability, the toughening of penalties is therefore difficult to justify in the context of deterrence or even punishment of tax fraud. Yet its potential for additional revenue collection is clear; audits may be a better deterrent, but they carry significantly more administrative costs and are therefore less efficient. ${ }^{110}$ Similar conclusions can be drawn as regards the recent tendency to engage in legal formalism, in the context of tax compliance obligations.

Although used in different contexts, legal formalism reflects a positivist theory of law. ${ }^{111}$ In tax law, legal formalism is often discussed in the context of substantive tax rules and tax avoidance, as a formalistic approach that facilitates the manipulation of legal rules and the granting of tax advantages where the letter of the law is complied with, even where its purpose is not. ${ }^{112}$ The term is rarely considered, if ever, from the perspective of procedural law. Yet, as the CJEU has demonstrated, the last decade has seen the adoption of an increasingly formalistic interpretation of compliance rules by member states'

104 L. Lederman, 'Tax Penalties as Instruments of Cooperative Tax Compliance Regimes' in Seer and Wilms (eds), op. cit., n. 92, 31, at 38-39 and 43.

105 Pomeranz, op. cit., n. 20; C. Agostini et al., 'Firms Response to Tax Enforcement through Audits' (2018) Oxford University Centre for Business Taxation Working Paper WP 18/09.

106 W. C. Boning et al., 'Heard It through the Grapevine: Direct and Network Effects of a Tax Enforcement Field Experiment' (2018) NBER Working Paper 24305.

107 J. E. de Neve et al., 'How to Improve Tax Compliance? Evidence from PopulationWide Experiments in Belgium' (2019) Said Business School Working Paper WP 2019-07. Negative results were found in earlier studies; see B. Ariel, 'Deterrence and Moral Persuasion Effects on Corporate Tax Compliance: Findings from a Randomized Controlled Trial' (2012) 50 Criminology 27.

108 G. Becker, 'Crime and Punishment: An Economic Approach' (1968) 76 J. of Political Economy 169. However, this theory's limitations have been known for some time; see M. Graetz and L. Wilde, 'The Economics of Tax Compliance' (1985) 38 National Tax J. 355 .

109 B. Meiselman, 'Ghostbusting in Detroit: Evidence on Nonfilers from a Controlled Field Experiment' (2018) $158 \mathrm{~J}$. of Public Economics 180.

110 Pomeranz, op. cit., n. 20; Plumley, op. cit., n. 84.

111 F. Schauer, 'Formalism' (1989) 97 Yale Law J. 509; B. Leiter, 'Legal Formalism and Legal Realism: What Is the Issue?' (2010) 16 Legal Theory 111.

112 D. Weisbach, 'Formalism in the Tax Law' (1999) 66 University of Chicago Law Rev. 860; D. McBarnet and C. Whelan, 'The Elusive Spirit of the Law: Formalism and the Struggle for Legal Control' (1991) 54 Modern Law Rev. 848. 
tax authorities to justify the denial of tax rights where evidence of fraud is neither apparent nor suspected.

Most of the cases decided by the CJEU in this regard have concerned invoicing rules, whereby the right to deduct VAT was refused on the basis of an error in the emission of an invoice: where the invoice contained inaccuracies, even though corrected invoices or other additional information had been subsequently submitted; ${ }^{113}$ where the invoice had been drawn before VAT registration; ${ }^{114}$ where the invoice had been amended; ${ }^{115}$ where the invoice was deemed to be too vague; ${ }^{116}$ and where the invoice did not include the VAT identification number of the acquirer of the goods. ${ }^{117}$ A similar formalistic approach to compliance rules has been reported at the national level, with German courts notably imposing criminal penalties for failing to immediately amend inaccurate VAT returns. ${ }^{118}$

In all of these cases, with one exception, ${ }^{119}$ the CJEU sided with the taxpayer, expressly rejecting a formalistic interpretation of the invoicing rules and adopting a substance-over-form approach. It has therefore consistently stated that where substantive requirements are satisfied, rights cannot be rejected on the basis of the failure to comply with the formal requirements. A similar approach has also been adopted in cases concerning other compliance rules, in particular accounting records, ${ }^{120}$ accounting of tax, ${ }^{121}$ and overpayment of tax. ${ }^{122}$ The most significant element in all of these cases is that in none was evasion alleged, and that in all there was clear evidence from the outset of the existence of a substantive right, despite the lack of respect for a formal requirement. As such, and similarly to recent trends concerning penalties, it is difficult to justify this legal formalism in respect of compliance rules in the context of deterrence or punishment of tax fraud. Its potential for additional revenue collection, however, is clear.

\section{The development of the principle of third-party liability}

Despite some recent EU-level measures, ${ }^{123}$ the feedback from EU member states indicated that traditional EU approaches to tackling organized fraud in

113 Case C-368/09, Pannon Gep Centrum, ECLI:EU:C:2010:441.

114 Case C-385/09, Nidera, ECLI:EU:C:2010:627.

115 Case C-518/14, Senatex, ECLI:EU:C:2016:691.

116 Case C-516/14, Barlis 06, ECLI:EU:C:2016:690.

117 Case C-587/10, VSTR, ECLI:EU:C:2012:592.

118 J. Meyer-Burrow and O. Stumm, 'Recent Developments in German Criminal Law and Their Impact on VAT Compliance' (2011) 3 International VAT Monitor 3.

119 Case C-271/12, Petroma Transports and Others, ECLI:EU:C:2013:297.

120 Case C-146/05, Collee, ECLI:EU:C:2007:549.

121 Case C-284/11, EMS-Bulgaria Transport, ECLI:EU:C:2012:458.

122 Case C-138/12, Rusedespred, ECLI:EU:C:2013:233.

123 See European Commission, On the Follow-Up to the Action Plan on VAT: Towards a Single EU VAT Area - Time to Act (2017) COM(2017) 566 final. 
particular were felt to be lacking. ${ }^{124}$ From the early 2000 s onwards, therefore, a new trend started to emerge amongst EU member states, with the adoption of new domestic legislation and administrative practices. Like measures concerning penalties or formalistic approaches to compliance, these new measures were purportedly aimed at strengthening anti-fraud policy in the context of organized fraud, yet their design means that by nature they cannot tackle fraud per se but merely minimize its revenue costs. Unsurprisingly, these measures have given rise to unprecedented levels of litigation, with dozens of cases reaching the CJEU. At the centre of litigation at the CJEU level - necessarily a small fraction of total litigation within the $\mathrm{EU}^{125}$ have been the legislative or administrative practices of only some member states: Austria, Belgium, Bulgaria, Germany, Greece, Hungary, Netherlands, Poland, and the UK. The suspicion, however, is that similar practices are being adopted in many other EU member states but that litigation is not reaching the CJEU; ${ }^{126}$ equally, there is evidence of similar practices being adopted in other countries outside the EU. ${ }^{127}$

What makes these cases so remarkable is the fact that, in all but a few, the taxpayers involved in the litigation were not those allegedly committing the fraud, but a third party with some business connection to the presumed fraudster. This third party could be the seller of the goods to the alleged fraudster, the purchaser of those goods, an intermediary, or even a warehouse keeper. The phenomenon whereby private parties not forming part of the criminal justice system are legally or administratively held responsible for crime prevention has been termed responsibilization, and is neither exclusive to VAT fraud nor new. As discussed below, this phenomenon has been identified as part of a general trend within crime control during the late twentieth century, ${ }^{128}$ which has spread in particular within criminal

124 European Commission, Report from the Commission to the Council and the European Parliament on the Application of Council Regulation (EU) No. 904/2010 Concerning Administrative Cooperation and Combating Fraud in the Field of Value Added Tax (2014) $\operatorname{COM(2014)~} 71$ final. See also S. Fedeli and F. Forte, 'EU VAT Frauds' (2011) 31 European J. of Law and Economics 143, at 162-163.

125 In the UK, the number of cases decided by domestic courts largely exceeded those that reached the CJEU. See M. Schofield, 'S\&I Electronics Plc v HMRC and the State of MTIC VAT Fraud' (2015) 5 Brit. Tax Rev. 663; K. Rahman and I. Roxan, 'Mobilx Ltd (in Administration) and others v. HMRC: Is This the End of Fraudulent Evasion of VAT?' (2010) 5 Brit. Tax Rev. 492.

126 On Italian practices, see M. Bancalari and F. T. Coaloa, 'The Unlawful Consequences of Italy's Registration Procedure' (2013) 3 International VAT Monitor 158. On Swedish practices, see E. Kristoffersson, 'Tax Fraud, Tax Abuse and the Right to Deduct Input VAT in Sweden' (2013) 2 World J. of VAT/GST Law 261.

127 On Canadian practices, see M. C. Marcil, 'The Recipient's Knowledge of Fraud and Its Impact on the Recovery of Refunds and Credits' (2013) 2 World J. of VAT/GST Law 214.

128 D. Garland, The Culture of Control: Crime and Social Order in Contemporary Society (2002). 
justice responses to financial crimes, such as money laundering. ${ }^{129}$ Why the phenomenon spread to VAT fraud and how it developed therein can be better understood by analysing the evolution of the CJEU case law on organized VAT fraud.

Perhaps unsurprisingly, given that the responsibilization phenomenon was first identified in the Anglo-American context, the process of responsibilization of third parties for VAT fraud seems to have started - at least within the EU - in the UK. In 2002, HMRC started refusing VAT refunds to traders where the purchaser of those goods had turned out to be a (missing trader) fraudster. The general view then was that this new approach was financially motivated and linked to the difficulty in catching fraudsters and the near-impossible task of recovering the revenue lost to fraud. ${ }^{130}$ Unsurprisingly, the new practice led to immediate litigation. Three cases, Optigen, Fulcrum, and Bond House, were soon lodged before the UK courts, and later referred to the CJEU. ${ }^{131}$ The resulting judgement became the first in a series of decisions that ultimately led to the establishment of the principle of third-party liability for VAT fraud. ${ }^{132}$

In that decision, the Court rejected third-party liability, concluding that, insofar as the taxable party had no knowledge and no means of knowledge of the fraud, it should be allowed to deduct input VAT, regardless of the existence of prior or subsequent fraudulent VAT transactions in the supply chain. ${ }^{133}$ This initial rejection was, however, soon significantly qualified in Kittel and Recolta Recycling, with the introduction of the concept of innocence: ${ }^{134}$ thirdparty liability for VAT fraud was possible where 'the recipient taxpayer knew, or should have known, that the goods were connected with the fraudulent evasion of VAT'. ${ }^{135}$ Whilst ascertaining knowledge of fraud is a matter of proof, the phrase 'should have known' raised immediate concerns as to its

129 E. Baker, 'The Legal Regulation of Transnational Organised Crime: Opportunities and Limitations' in Transnational Organised Crime, eds A. Edwards and P. Gill (2003) 183.

130 R. Pincher, 'The Costs of VAT Frauds: Bond House Systems Ltd and Optigen' (2003) 5 Brit. Tax Rev. 346.

131 G. Richards, 'Carousel Fraud: Absolving the Innocent: Optigen Ltd and Others $v$ Commissioners of Customs \& Excise' (2006) 2 Brit. Tax Rev. 147.

132 For a comprehensive analysis of the jurisprudential development of the principle, see R. de la Feria and R. Foy, 'Italmoda: The Birth of the Principle of Third-Party Liability for VAT Fraud' (2016) 4 Brit. Tax Rev. 262.

133 Joined Cases C-354/03, C-355/03, and C-484/03, ECLI:EU:C:2006:16. See also S. Vandenberghe and H. J. Sharkett, 'Rights of Taxable Persons Involved in VAT Carousel Fraud from an EU, Belgian and UK Point of View Today and Tomorrow' (2006) 17 International VAT Monitor 254.

134 Joined Cases C-439/04 and C-440/04, ECLI:EU:C:2006:446. See also I. Lejeune et al., 'Limited Third-Party Liability in the EU VAT Matters' (2012) 6 International VAT Monitor 397.

135 Joined Cases, id., at para. 14. 
meaning and scope. ${ }^{136}$ From that point forth, the CJEU case law on third-party liability for VAT fraud was divided into two streams: (1) cases concerning the burden of proof for establishing liability, ${ }^{137}$ and (2) cases concerning the scope of that liability.

In terms of the scope of liability, the first question then was whether thirdparty liability for fraud could be extended to the removal of other rights, in particular the right to VAT exemption on intra-EU sales, if the acquirer of those products turned out to be a fraudster. Although the CJEU implicitly accepted the potential denial of those rights earlier, ${ }^{138}$ express confirmation only came in the Mecsek-Gabona case. ${ }^{139}$ Whilst at the time this extension may have appeared to be a small legal step, in reality it was an extremely significant one. Indeed, there are fundamental differences between making a business that acquired products from a fraudster liable, by denying the right to deduct input VAT, and making a business that supplied goods to a potential fraudster liable, by denying the right to VAT exemption. Both instances constitute third-party liability for unknowing participation in organized VAT fraud, in the form of denial of rights. Yet denying deductibility to the acquirer of goods constitutes the imposition of liability for a crime that has already occurred and has been committed in the same country that is now imposing the liability; by contrast, denying the right to VAT exemption on intra-EU sales to the supplier of goods amounts to the imposition of liability for a crime that has not yet occurred and that will be committed extraterritorially. ${ }^{140}$ The responsibilization for a crime that has not yet occurred is not unique to VAT fraud and can been seen as part of a wider shift to a pre-crime society, where crime is conceived essentially as risk or potential loss, and practices are preemptive as opposed to post hoc. ${ }^{141}$ Insofar as the extraterritoriality element is concerned, the extension of the scope of third-party liability creates the opportunity for the imposition of double liability for a single crime, yielding double the revenue than what has been lost to the actual fraud: where both the

136 Similar wording is often used in the context of money laundering and income tax evasion; see Alldridge, op. cit., n. 19, at 170-174.

137 Cases C-384/04, Federation of Technological Industries and Others, ECLI:EU:C:2006:309; C-409/04, Teleos plc and Others, ECLI:EU:C:2007:548; C-277/14, PPUH Stehcemp, ECLI:EU:C:2015:719. See also Y. Serandour, 'Establishing VAT Fraud in the Case of Cross-Border Supply' (2012) 1 World J. of VAT/GST Law 95.

138 Case C-409/04, Teleos plc and Others, ECLI:EU:C:2007:548. See also S. Nathoeni and W. de Wit, 'VAT Exemptions of Intra-Community Supplies of Goods: State of Play after VSTR' (2013) 2 EC Tax Rev. 100.

139 Case C-273/11, ECLI:EU:C:2012:547. See also R. Wolf, 'Mecsek-Gabona: The Final Step of the ECJ's Doctrine on Reliance on EU Law for Abusive or Fraudulent Ends in the Context of Intra-Community Transactions' (2013) 5 International VAT Monitor 280.

140 M. Sutich and P. Centore, 'Denial of a Right and Extraterritoriality: Strengthening the Fight against Tax Fraud' (2015) 4 World J. of VAT/GST Law 101.

141 L. Zedner, 'Pre-Crime and Post-Criminology?' (2007) 11 Theoretical Criminology 261. 
supplier (A) and the acquirer (C) are made liable for fraud committed by a fraudster (B). Cases of the imposition of double liability for one instance of organized VAT fraud have already been reported - a de facto economic double taxation through enforcement. ${ }^{142}$

As significant as this extension has been, it has still only concerned the removal of rights. The most recent debate regarding the scope of the thirdparty liability has been whether it extends beyond organized VAT fraud to all VAT fraud, and from the possible removal of rights to include the imposition of obligations. The answer finally came in the Court's landmark decision in Italmoda ${ }^{143}$ in which it established that the liability for VAT fraud can arise in the absence of national legislation providing for it, ${ }^{144}$ which in essence transformed third-party liability for VAT fraud from a rule into a principle. This has significant theoretical and practical implications: the scope of the new principle of third-party liability for tax fraud, as developed by the Court, appears to apply to any type of fraud and to extend to the potential creation of VAT obligations to any party within the production chain, including intermediaries such as warehouse owners or online retail platforms; and it is now implicitly endorsed in new EU provisions, which determine that online retail platforms will be held liable for unpaid import VAT. ${ }^{145}$

\section{Third-party liability as aggravated responsibilization}

The phenomenon of responsibilization emerged as a new mode of governing crime in the late twentieth century. ${ }^{146}$ Prompted by a series of transformations in perceptions of crime and criminal justice structures, and the policy decision that the state could no longer assume sole responsibility for crime control, ${ }^{147}$ governments sought to devolve responsibility for crime prevention to organizations and individuals outside the state. Once the new strategy was established, it became a case of identifying those private organizations and individuals who should have the responsibility for reducing crime opportunities effectively. Responsibilization of the private sector with regards to fraud and money laundering became commonplace, ${ }^{148}$ with financial

142 M. Malecka, 'Not Your Business but Your Liability: New VAT Third-Party Liability in Poland' (2013) 2 World J. of VAT/GST Law 253.

143 Joined Cases C-131/13, C-163/13, and C-164/13, EU:C:2014:2455.

144 Concerns have been already raised; see J. Sanders, 'The ECJ Decision in Italmoda in the Light of the Settled Case Law of the European Court of Human Rights' (2016) 6 International VAT Monitor 421.

145 Council Directive 2017/2455/EU [2017] OJ L 348/7.

146 D. Garland, 'The Limits of the Sovereign State: Strategies of Crime Control in the Contemporary Society' (1996) 36 Brit. J. of Criminology 445.

147 Id., at 448. See also S. Schneider, 'Privatising Economic Crime Enforcement: Explaining the Role of Private Sector Investigative Agencies in Combating Money Laundering' (2006) 16 Policing and Society 285.

148 Levi and Burrows, op. cit., n. 23. 
institutions bearing the brunt of the responsibility. ${ }^{149}$ Responsibilization then spread to other areas, such as cybercrime, with the telecommunications and financial industries acquiring key roles in crime control. ${ }^{150}$

The extension of responsibilization to tax fraud was progressive, with some instances dating back many years ${ }^{151}$ and empirical evidence strongly indicating that third-party information reporting played an important role in tax compliance. ${ }^{152}$ However, the development of the principle of thirdparty liability marks a new stage in both the acknowledgement ${ }^{153}$ and the scope of the responsibilization of the private sector for tax enforcement. ${ }^{154}$ This responsibilization, under the principle of third-party liability, has one key difference from other instances of responsibilization: as in other areas, it privatizes crime control, but by contrast, it also privatizes (some of) the costs of crime. Under the principle of third-party liability, businesses are required to carry out due diligence to ensure that their business partners are not involved in fraud - and, as such, carry responsibility for crime control. ${ }^{155}$ Where the tax authorities present objective evidence that businesses should have known that fraud was being committed, those businesses lose the right to exercise their rights to a tax refund or tax exemption, and may be held liable for the tax that went unpaid; in this case, therefore, they carry the responsibility for the revenue costs of the fraud, which are transferred to them through the denial of tax rights or the imposition of new tax obligations. This transfer has a detrimental impact upon businesses which, whilst uncommon in the context of responsibilization, is quite common within criminal justice systems through asset confiscation regimes.

Asset confiscation regimes have existed in several countries for many years, but the same transformations that led to the development of responsibilization in the late twentieth century also led to a renewed emphasis on these regimes

149 Council Directive 2015/849/EU [2015] OJ L 141/73. See also V. Mitsilegas and N. Vavoula, 'The Evolving EU Anti-Money Laundering Regime: Challenges for Fundamental Rights and the Rule of Law' (2016) 23 Maastricht J. of European and Comparative Law 261.

150 K. Uchimira, 'Third-Party Responsibilisation through Telecoms Policing' in CyberCrime: The Challenge in Asia, eds R. Broadhurst and P. Grabosky (2005) 109.

151 A. Desai, 'What a History of Tax Withholding Tells Us about the Relationship between Statutes and Constitutional Law' (2014) 108 Northwestern University Law Rev. 859.

152 L. Lederman, 'Statutory Speed Bumps: The Roles Third Parties Play in Tax Compliance' (2007) 60 Stanford Law Rev. 695; Pomeranz, op. cit., n. 20.

153 M. Griffioen and L. van der Het van Dijk, 'New European Approach to Combat VAT Fraud' (2014) 42 Intertax 298.

154 The principle is spreading to other taxes; see R. Seer and A. L. Wilms, 'General Report' in Seer and Wilms (eds), op. cit., n. 92, 3, at 26.

155 B. Gunacker-Slawitsch, 'The Knowing Participation in VAT Fraud: Reflections on the Contents and the Limits of a Reasonable Duty of Due Diligence' (2017) 5 Brit. Tax Rev. 649. 
as part of a trend towards a 'follow-the-money approach' in crime control. ${ }^{156}$ These new confiscation regimes allow various types of confiscation, including non-conviction-based confiscation, in which the confiscation of assets is pursued under civil proceedings, detached from criminal proceedings and regardless of their existence. This type of confiscation is usually justified on the basis of one or more of the following elements: (1) deterrence, by preventing the use of the proceeds of crime; ${ }^{157}$ (2) prevention, by hindering re-investment; (3) restoration of the status quo that would have existed if crime had not been committed; and (4) remedy, by compensating the victims of crime conduct, or the state for costs related to law enforcement. Underlying these justifications are two key considerations: (1) efficiency, as the potentially higher costs and risks of criminal proceedings are avoided; ${ }^{158}$ and (2) a moral imperative, rather than a rational one, according to which no one should benefit from their crimes. ${ }^{159}$ Both the justifications and the underlying considerations assume that non-conviction-based asset confiscation targets criminal proceeds, thereby tackling crime in rem and ensuring a restitutionary effect.

Yet, insofar as the principle of third-party liability is concerned, it is not the proceeds of crime that are being targeted, and there is no restitutionary effect; on the contrary, there is a substitution effect, whereby the proceeds of crime - the revenue lost through fraud - are being collected from a third party. In this context, most justifications and underlying considerations for asset confiscation do not apply. There is no moral imperative, since the crime was committed by a different party to that from whom the assets are being confiscated. Similarly, there is no element of deterrence, prevention, or restoration of the status quo; indeed, the collection of revenue from others may create a moral hazard, resulting in an increase in the incidence of fraud. There are therefore only two possible justifications for the existence of elements akin to asset confiscation in anti-fraud policy: (1) remedy, to the extent that it allows compensation to the state for the revenue lost through fraud - although it does not compensate other victims of tax fraud, such as businesses who were put at a competitive disadvantage; and (2) efficiency, since it allows a quick recovery of the revenue lost through fraud, with minimal enforcement costs.

156 J. Boucht, The Limits of Asset Confiscation: On the Legitimacy of Extended Appropriation of Criminal Proceeds (2017), at 5; C. King and C. Walker, 'Emerging Issues in the Regulation of Criminal and Terrorist Assets' in Dirty Assets: Emerging Issues in the Regulation of Criminal and Terrorist Assets eds C. King and C. Walker (2014) 36, at 5 .

157 R. Bowles et al., 'Economic Analysis of the Removal of Illegal Gains' (2000) 20 International Rev. of Law and Economics 537.

158 J. Boucht, op. cit., n. 156, at 10; J. Hendry and C. King, 'Expediency, Legitimacy, and the Rule of Law: A Systems Perspective on Civil/Criminal Procedural Hybrids' (2016) 10 Criminal Law and Philosophy 1, at 10.

159 M. Beare and F. Martens, 'Policing Organised Crime: The Comparative Structures, Traditions, and Policies within the United States and Canada' (1998) 14 J. of Contemporary Criminal Justice 398, at 415. 
The principle of third-party liability for tax fraud can therefore be characterized as an instance of responsibilization with aggravating elements that are more akin to asset confiscation. Yet even in their purest form, these criminal justice trends have been subjected to intense scrutiny and their legitimacy questioned. Non-conviction-based asset confiscation is regarded as a paradigmatic example of the trend towards the hybridization of procedures, in which civil procedures are used to target criminal behaviour. ${ }^{160}$ The absence from civil proceedings of the procedural protections that are present in criminal proceedings, however, has been said to threaten civil liberties and the rule of law, ${ }^{161}$ as well as to create the risk of targeting legitimate possessions, with potentially stigmatizing and reputational effects, and even adverse personal effects, on those who have been subjected to it. ${ }^{162}$ Put in the context of the principle of third-party liability for tax fraud, these concerns are much more pronounced, as the features akin to non-conviction-based asset confiscation are applied in conjunction with responsibilization. As a result, the sanction is applied not to the fraudsters (there is no presumption or pretence that the target is the proceeds of crime) but rather to third parties, who have not themselves committed the crime - one that may have been committed extrajurisdictionally or that may even have not yet been committed at all. It is therefore third parties, not those who commit fraud, who feel any potential financial, stigmatizing, reputational, or personal negative effects resulting from the targeting of their property by tax authorities.

\section{FROM TAX FRAUD SUPPRESSION TO TAX FRAUD MANAGEMENT}

Anti-fraud measures, like other criminal law measures, have traditionally centred primarily on a dual function: punishment and deterrence. The recent legal and administrative developments discussed above have cast doubts over the effectiveness of such measures. Increasing penalties has been shown to have a limited deterrent effect on tax evasion; the emphasis on legal formalism has resulted in the denial of tax rights even where there is no evidence or risk of evasion; and the aggravated responsibilization of third parties for organized tax fraud has meant that they are now liable even where they are only remotely connected with the fraudster and there is no evidence or risk of fraud. Overall, these measures are evidence of a shift in tax enforcement approaches, whereby the main effect of anti-fraud measures, supposedly aimed at combating either tax evasion or organized tax fraud, is no longer punishment or deterrence, but

160 A. Ashworth and L. Zedner, 'Defending the Criminal Law: Reflections on the Changing Character of Crime' (2008) 2 Criminal Law and Philosophy 21.

161 Hendry and King, op. cit., n. 158, at 22. See also J. Sheptycki, 'Global Law Enforcement as a Protection Racket' in Edwards and Gill (eds.), op. cit., n. 129, 42.

162 Boucht, op. cit., n. 156. 
rather the maximization of revenue gains, regardless of whether those gains are the result of curtailing tax fraud or of the above measures being applied to non-fraudsters.

These developments as regards tax fraud are reminiscent of wider developments in criminal justice: a general move in crime control from suppression to management. The main focus of anti-fraud policy now seems to be oriented towards managing the revenue costs of tax fraud rather than suppressing it. In many situations, the two will coincide: measures aimed at addressing the revenue costs of fraud will have a positive effect in the reduction of the incidences of tax fraud itself. This will not necessarily be the case, however, and where the two diverge, pre-eminence is now consistently being given to maximizing revenue, or minimizing the revenue costs of tax fraud, to the detriment of eliminating fraud itself.

The question that then arises is: what has prompted this shift in tax law enforcement? The answer seems to lie in a mixture of exogenous factors, resulting to a large extent from the 2008/2009 financial crisis, and endogenous factors, some of which are common to other areas of law enforcement. The financial crisis gave rise to significant and widespread public finance concerns, resulting in pressures for both an increase in revenues and a reduction in expenditure. In many countries, such pressures resulted in two concurrent policy effects: (1) the use of tax policy measures to increase revenue, and (2) the introduction of austerity measures to reduce expenditure. Both of these policy effects had an impact on anti-fraud policy. ${ }^{163}$ From a tax policy perspective, the intensification of anti-fraud measures was perceived as an obvious (and equitable) method of raising revenues without increasing the tax burden on the overall population. From an expenditure perspective, the imposition of austerity measures fuelled recognition of tax fraud as a crime, ${ }^{164}$ leading in turn to political economy pressures. Whilst little is known about the electoral impact of anti-fraud measures, recent evidence indicates a positive correlation between such measures and political gains: the implementation of new anti-fraud measures increases the support for, and likelihood of reelection of, political incumbents. ${ }^{165}$ Political gains are more pronounced in areas with a lower self-reported tolerance for tax evasion and more efficient public services, which may explain the higher intensity of anti-fraud initiatives in some countries when compared to others.

Beyond public finance and political economy pressures, there are also endogenous factors that can partially explain the shift evidenced in tax

163 Levi, op. cit., n. 27.

164 D. Wilks et al., "Please Give Me an Invoice": VAT Evasion and the Portuguese Tax Lottery' (2019) 39 International J. of Sociology and Social Policy. On how perceptions of tax fraud have altered over time, see generally S. Karlinsky et al., 'Perceptions of Tax Evasion as a Crime' (2004) 2 E-J. of Tax Research 226; G. S. Moohr, 'Tax Evasion as White Collar Fraud' (2009) 9 Houston Business \& Tax Law J. 207.

165 Casaburi and Troiano, op. cit., n. 64. 
enforcement. Tax enforcement is costly, and the more organized the fraud is, the more costly enforcement is likely to be. It is therefore common - and natural - for tax administrations to assess the relative effectiveness of a range of measures to encourage compliance: designing administrative actions in light of enforcement elasticities or, more generally, of the marginal revenue and costs associated with these actions is perceived as necessary for optimal tax administration. ${ }^{166}$ The difficulty lies, however, in the fact that these effectiveness assessments are based solely on cost-benefit analyses that factor in only the short-term revenue results of tax administrations' measures. Revenue maximization is therefore used as a proxy for effectiveness, ${ }^{167}$ without consideration of other costs of fraud. Taking this approach can easily lead to the maximization of revenues regardless of fraud itself; the administrative costs of combating fraud are such that 'dispensing with the problems it poses', ${ }^{168}$ namely revenue loss, is perceived as more effective.

Related to the focus on revenue maximization is the use of revenue performance statistics and incentives. There is evidence that tax enforcement activity has gravitated towards tackling the 'low-hanging fruit': tax authorities are likely to focus on cases that increase their revenue but incur low administrative costs, thus improving performance statistics. ${ }^{169}$ This phenomenon is not exclusive to tax authorities; rather, it is part of a wider trend in law enforcement agencies, whereby these agencies are evaluated with reference to performance indicators. ${ }^{170}$ Where these indicators are linked to performance incentives, the effects - and the risks - are amplified. Such incentives have become commonplace within tax administrations worldwide, with many applying performance-related pay or promotions, ${ }^{171}$ and have proven to be extremely successful in boosting revenues. ${ }^{172}$ There is evidence that the application of performance-related pay may increase

166 M. Keen and J. Slemrod, 'Optimal Tax Administration' (2017) IMF Working Paper WP/17/8, at 18. See also E. Crivelli, 'A Basic Tool to Assess Tax Administration Strength in Emerging Europe' (2018) 26 Economics of Transition 1.

167 Y. Kuchumova, 'The Optimal Deterrence of Tax Evasion: The Trade-Off between Information Reporting and Audits' (2017) 145 J. of Public Economics 162.

168 Opinion of Advocate General Maduro in Case C-354/03, Optigen and Others, ECLI:EU:C:2005:89.

169 Braithwaite, op. cit., n. 63, at 200; D. Roche, 'Tax Office Prosecutions: Firm and Fair Regulatory Enforcement' (2006) Australia National University Occasional Paper 9; Malecka, op. cit., n. 142, at 260.

170 Garland, op. cit., n. 146, at 458.

171 A. Khan et al., 'Tax Farming Redux: Experimental Evidence on Performance Pay for Tax Collectors' (2016) 131 Q. J. of Economics 219, at 220. See also C. M. Kahn et al., 'Performance-Based Wages in Tax Collection: The Brazilian Tax Collection Reform and Its Effects' (2001) 11 Economic J. 188; M. Holehouse, 'I Deserve £20,000 Bonus, Says HMRC Chief’ Telegraph, 17 July 2014, at <http://www.telegraph.co.uk/finance/ personalfinance/tax/10972205/I-deserve-20000-bonus-says-HMRC-chief.html> .

172 F. Flatters and W. B. MacLeod, 'Administrative Corruption and Taxation' (1995) 2 International Tax and Public Finance 397. 
revenues by up to 40 per cent, ${ }^{173}$ whilst performance-related postings to highly desirable locations may increase revenues by up to 80 per cent. ${ }^{174}$ There is also evidence of the reallocation of resources in response to the introduction of performance incentives, to activities that will trigger those incentives. ${ }^{175}$ This success comes, however, at a price: performance incentives increase inspectors' bargaining power, encouraging overzealous and improper behaviour, including extortion and bribery. ${ }^{176}$

The impact of performance incentives within tax administrations is in line with findings regarding other law enforcement agencies. There is significant indication that the approval of asset confiscation legislation, which allowed US police departments to keep part of the confiscated funds from drug-related crimes, created revenue dependency ${ }^{177}$ and distorted police behaviour, ${ }^{178}$ leading some to argue that the notion of 'policing for profit' could not be dismissed. ${ }^{179}$ Indeed, not only did the legislation lead to sharp increases in drug arrests, but there was also evidence of associated costly negative externalities, such as a 22 per cent increase in traffic fatalities, as resources were reallocated from activities that were not rewarded with performance incentives (traffic control) to those that were (drug control). Concerns over these distortive effects were reportedly behind the decision taken in Canada to distribute all financial gains resulting from asset confiscation amongst the various divisions of the police force, rather than allowing those directly connected to the case to keep all of the profits. ${ }^{180}$

Whilst the above factors explain the shift in tax enforcement from tax fraud suppression to managing the revenue effects of fraud, the clear parallels with other areas of criminal justice system also highlight the risks that such a shift entails. Overall, there are two overarching concerns: (1) the risk of increasing

173 A. Khan et al., op. cit., n. 171.

174 A. Khan et al., 'Making Moves Matter: Experimental Evidence on Incentivizing Bureaucrats through Performance-Based Postings' (2018) NBER Working Paper 24383.

175 C. M. Kahn et al., op. cit., n. 171, at 204.

176 Khan et al., op. cit., n. 174; C. M. Kahn et al., op. cit., n. 171.

177 Beare and Martens, op. cit., n. 159; N. Taifa, 'Civil Forfeiture versus Civil Liberties' (1994) 39 New York Law School Rev. 95.

178 B. L. Benson et al., 'Police Bureaucracies, Their Incentives, and the War on Drugs' (1995) 83 Public Choice 21; B. D. Mas et al., 'Entrepreneurial Police and Drug Enforcement Policy' (2000) 104 Public Choice 85; K. Baicher and M. Jacobson, 'Finders Keepers: Forfeiture Laws, Policing Incentives, and Local Budgets' (2007) 91 J. of Public Economics 2113.

179 S. Kantor et al., 'Civil Asset Forfeiture, Crime, and Police Incentives: Evidence from the Comprehensive Crime Control Act of 1984' (2017) NBER Working Paper 23873, at 7; M. M. Cheh, 'Can Something This Easy, Quick, and Profitable Also Be Fair?' (1994) 39 New York Law School Rev. 1.

180 Beare and Martens, op. cit., n. 159. However, this was subsequently changed in some Canadian provinces; see M. Levi, 'Reflections on Proceeds of Crime: A New Code for Confiscation?' in Criminal Law Reform Now, eds J. Child and A. Duff (2018) 1. 
tax fraud, and all of the costs associated with it (beyond just revenue loss); and (2) equally significantly, the risk to the rule of law.

There are two main reasons why tax fraud, and the non-revenue costs resulting from it, can increase as a result of the shift in tax enforcement. ${ }^{181}$ The first is that eliminating the revenue costs of tax fraud - through increased penalties, legal formalism, or aggravated responsibilization - removes the incentives to combat tax fraud itself. Beyond the evidence regarding reallocation of resources as a result of performance indicators and incentives, there is also evidence that, even in the absence of these, the emergence of new revenue streams can result in looser tax enforcement. ${ }^{182}$ The second reason is that prioritizing the elimination of revenue costs, to the detriment of combating fraud per se, decreases rather than increases deterrence by creating a moral hazard. For tax fraudsters, impunity encourages re-incidence, as it increases the expected value of the fraud; for non-fraudsters, perceived inequity in the tax system encourages defiant non-compliance. ${ }^{183}$

The risk of this shift in tax enforcement to the rule of law is also significant. The legitimacy of many of the criminal justice trends beyond the recent developments in tax enforcement has long been questioned. Yet what is happening within tax systems is much more extreme. The hybridization of procedures is being applied not to address criminal behaviour but to address some of the costs of that criminal behaviour; responsibilization is not being applied per se but with features of asset confiscation, leading to a new phenomenon of aggravated responsibilization. Furthermore, many of these measures have been implemented not through legislation but through administrative practice, and whilst it is generally accepted that tax authorities need to employ some discretion in the exercise of their duties, that discretion is subject to the limits resulting from legal and constitutional principles, including the rule of law. ${ }^{184}$ The recent shift in tax enforcement, as much a result of administrative discretion as of legislative developments, does not respect the key principles from which it stems.

Even in a (narrower) formal conception, the rule of law imposes the respect for principles that result in significant limitations on tax enforcement, not least the principle that the discretion that law enforcement agencies possess should

181 E. Auriol and M. Warlters, 'Taxation Base in Developing Countries' (2005) 89 J. of Public Economics 625; M. Keen, 'Taxation and Development - Again' in Studies of Critical Issues in Taxation and Development, eds C. Fuest and G. Zodrow (2013) 13.

182 S. X. Chen, 'The Effect of a Fiscal Squeeze on Tax Enforcement: Evidence from a Natural Experiment in China' (2017) 147 J. of Public Economics 62.

183 See Braithwaite, op. cit., n. 63. Here lies a key paradox in regulatory theory: responsive regulation, to the extent that it concentrates on the revenue lost through fraud, may itself increase non-compliance by creating perceptions of inequity, undermining the cognitive reframing of tax morality on which it relies.

184 J. Freedman and J. Vella, 'HMRC's Management of the UK Tax System: The Boundaries of Legitimate Discretion', and D. de Cogan, 'Tax, Discretion and the Rule of Law', in C. Evans et al. (eds.), The Delicate Balance: Tax, Discretion and the Rule of Law (IBFD, 2011) 1-13 and 63-77. 
not be allowed to undermine the purposes of the relevant legal rules, ${ }^{185}$ and the principle that no one should be punishable or lawfully made to suffer in body or goods except for a distinct breach of law. ${ }^{186}$ An anti-fraud policy that gives precedence to minimizing the revenue costs of tax fraud or maximizing revenue, rather than to combating tax fraud itself, inevitably leads to selective tax enforcement. Whilst full tax enforcement is of course impossible to achieve, selective enforcement based on maximization of revenue, rather than minimization of tax fraud, runs counter to those two key corollary principles of the rule of law. Ad extremis selective tax enforcement would allow tax administrations to overlook the collection of a tax, imposed by law, that raised low amounts of revenue but was costly to collect. ${ }^{187}$ At a fundamental level, selective tax enforcement allows (tax) law to be sacrificed at the altar of administrative tax effectiveness.

\section{CONCLUSION}

The last decade has witnessed the significant intensification of anti-fraud policy both within Europe and elsewhere, with an upsurge in both legislative and administrative measures that purportedly target different types of tax fraud. Whilst many of these should be regarded as positive developments, analysis of some of them - both those supposedly designed to address tax evasion and those purportedly targeting organized tax fraud - unveils a crucial shift in dominant approaches to tax enforcement, which, although in line with those witnessed in other areas of crime control and the criminal justice system, displays a fundamental lack of understanding of the phenomenon of tax fraud and its costs. A mixture of exogenous and endogenous factors have progressively and perniciously resulted in a situation whereby revenue loss is taken as a proxy for tax fraud, and anti-fraud measures are designed primarily not to deter or to punish fraud but rather to facilitate the recovery of, or (failing that) to allow compensation for, the revenue that has been lost through fraud. As in many other areas of the criminal justice system, tax fraud has become a crime whose effects are to be managed, rather than a crime to be suppressed. This has a profound effect upon our tax systems, which are a cornerstone of our societies. Tax systems are dependent on enforcement

185 P. Craig, 'Formal and Substantive Conceptions of the Rule of Law: An Analytical Framework' (1997) Public Law 467. See also J. Raz, The Authority of Law: Essays on Law and Morality (2009) Chapter 11.

186 Craig, id. See also T. R. S. Allan, Law, Liberty and Justice: The Legal Foundations of British Constitutionalism (1993), at 46.

187 This example is borrowed from J. Freedman and J. Vella, 'Revenue Guidance: The Limits of Discretion and Legitimate Expectations' (2012) 128 Law Q. Rev. 192, at 195. It bares strong similarities to that reported in UK House of Commons Committee of Public Accounts, Tackling Online VAT Fraud and Error, First Report of Session 2017-19, October 2017. 
as much as on policy. ${ }^{188}$ Selective tax enforcement that gives primacy to revenue maximization and short-term efficiency concerns fatally damages the neutrality and equity of our overall tax systems; ${ }^{189}$ it results in a decrease in the long-term efficiency of those systems; ${ }^{190}$ and, crucially, it undermines the rule of law, slowly corroding one of the core values upon which our societies are based.

188 R. Bird, ‘Administrative Dimensions of Tax Reform' (2014) 15 Annals of Economic Finance 963, at 963.

189 Freedman and Vella, op. cit., n. 187; Bird, id.

190 This is as a result of the theory of the second best; see R. Markovits, 'The General Theory of the Second Best and Economic Efficiency Analysis' (2015) 49 Akron Law Rev. 467. 